\title{
Anti-Inflammatory Meroterpenoids of Cordia glazioviana (Boraginaceae)
}

\author{
Ana Karine O. Silva, ${ }^{\oplus a}$ Francisco C. L. Pinto, ${ }^{\circledR a}$ Kirley M. Canuto, ${ }^{\circ} b$ Raimundo Braz-Filho, ${ }^{\odot c}$ \\ Rose Anny C. Silva, ${ }^{\oplus d}$ Flávia A. Santos, ${ }^{\circledR e}$ Norberto K. V. Monteiro, ${ }^{\circledR f}$ Edilberto R. Silveira $^{\circledR a}$ and \\ Otília D. L. Pessoa ${ }^{\circledR} * a$ \\ ${ }^{a}$ Departamento de Química Orgânica e Inorgânica, Universidade Federal do Ceará, \\ 60021-970 Fortaleza-CE, Brazil \\ ${ }^{b}$ Embrapa Agroindústria Tropical, 60511-110 Fortaleza-CE, Brazil \\ 'Departamento de Química, Universidade Estadual do Norte Fluminense Darcy Ribeiro, \\ 28013-602 Campos dos Goytacazes-RJ, Brazil \\ ${ }^{d}$ Departamento de Medicina Clínica, Universidade Federal do Ceará, \\ 60430-140 Fortaleza-CE, Brazil \\ ${ }^{e}$ Departamento de Fisiologia e Farmacologia, Universidade Federal do Ceará, \\ 60165-085 Fortaleza-CE, Brazil \\ ${ }^{f}$ Departamento de Química Analítica e Fisico-Química, Universidade Federal do Ceará, \\ 60461-970 Fortaleza-CE, Brazil
}

The phytochemical reinvestigation from the heartwood of the extracts of Cordia glazioviana led to the isolation of four still undescribed hydroquinones derivatives designated as cordiaquinol D (1), cordiaquinol E (2), (10R)-10,11-dihydrofuran-1,4-dihydroxy-globiferin (3) and 2-[(1'E,6' $E)-3$ ', 8'-dihydroxy-3',7'-dimethylocta-1',6'-dienyl]-benzene-1,4-diol (4), along with the naphthoquinone 6-[(2' $R)-2^{\prime}$-hydroxy-3',6'-dihydro- $2 H$-pyran-5'-yl]-2-methoxy7-methylnaphthalene-1,4-dione (5). Additionally, six previously known compounds were also isolated: rel-1,4-dihydroxy- $8 \alpha, 11 \alpha ; 9 \alpha, 11 \alpha$-diepoxy-2-methoxy-8a $\beta$-methyl5,6,7,8,8a,9,10,10a-octahydro-10-antracenone (6), didehydroconicol (7), 1 $\beta, 6 \beta$-dihydroxy-7-epieudesm-3-ene (8), 1 $\beta, 6 \beta$-dihydroxy-7-epi-eudesm-4(15)-ene (9), 10,11-dihydroxybisabolol (10), and hamanasal-A (11). The structures of the new compounds were assigned by high-resolution mass spectrometry (HRMS) and nuclear magnetic resonance (NMR) analyses. The relative stereochemistry of $\mathbf{3}, \mathbf{4}$, and $\mathbf{5}$ was improved by quantum mechanical calculations. Eight, out of the eleven isolated compounds (2-9), were tested through cellular viability and lipopolysaccharide (LPS)-induced inflammation assays against RAW 264.7 macrophage-like cells. Compounds 3-5 exhibited a stronger effect on LPS-induced NO production (half-maximal inhibitory concentration $\left(\mathrm{IC}_{50}\right) 50.34,105.83$, and $66.73 \mu \mathrm{M}$, respectively).

Keywords: Cordia glazioviana, Boraginaceae, hydroquinones, naphthoquinones, antiinflammatory activity

\section{Introduction}

Plants of the genus Cordia (Boraginaceae) have been described as a prolific source of bioactive compounds. ${ }^{1}$ In fact, several Cordia species (C. dichotoma, C. latifolia, C. verbenacea, C. myxa, C. rothii, C. gharaf, C. obliqua, etc.) have been used in different traditional systems of

*e-mail: otilialoiola@gmail.com medicine around the world such as the Ayurveda, Unani, and Siddha ${ }^{2}$ due to their ethnopharmacological properties: anti-inflammatory, antimicrobial, anthelmintic, analgesic, and diuretic. ${ }^{1}$

Despite the wealthy Brazilian biodiversity, the great traditional knowledge and acceptance of medicinal plants, in contrast to the increasing world demand for phytotherapeutics, the Brazilian herbal medicine market is still very modest. Nevertheless, it is worthwhile to 
highlight that an anti-inflammatory product incorporative Cordia verbenacea essential oil, is found among the top 20 pharmaceutical drugs marketed in Brazil in 2016. ${ }^{3}$ Moreover, recent studies have evidenced the antiinflammatory potential of extracts and pure compounds from other Cordia species. ${ }^{4}$

Previous phytochemical studies ${ }^{5,6}$ on Cordia genus have reported the isolation of terpenoids, particularly sesquiterpenes and triterpenes, meroterpenoid benzoquinones, and naphthoquinones as well as their respective hydroquinones. Furthermore, the antiinflammatory effect of sesquiterpenes, ${ }^{7}$ triterpenes, ${ }^{8}$ hydroquinones, ${ }^{9}$ and naphthoquinones ${ }^{10}$ have been demonstrated.

Cordia glazioviana (Auxemma glazioviana), an endemic Brazilian plant, is largely widespread in the "caatinga" (the characteristic biome of northeastern Brazil). ${ }^{11}$ In folk medicine, the water decoction from its barks is indicated to the healing of small cuts and wounds. ${ }^{6}$ Previous reports ${ }^{6,12}$ on C. glazioviana described the isolation of sesquiterpenes and terpenoids benzoquinones, as well as hydroquinones. Thus, encouraged by the new perspective, we decided to reinvestigate the extracts of $C$. glazioviana pursuing the isolation of anti-inflammatory natural chemical compounds.

\section{Results and Discussion}

Eleven meroterpenoid compounds including sesquiterpenes, hydroquinones, and naphthoquinones, five of which previously unreported (1-5), were isolated from the ethanol (EtOH) extract of the heartwood of C. glazioviana (Figure 1).

Compound 1 had its molecular formula established as $\mathrm{C}_{17} \mathrm{H}_{18} \mathrm{O}_{5}$ by high-resolution electrospray ionization mass spectrometry (HRESIMS) through the deprotonated molecule $[\mathrm{M}-\mathrm{H}]^{-}$at $m / z 301.1076$ (calcd. $m / z$ 301.1081). Its infrared (IR) spectrum indicated absorption bands for hydroxy $\left(3405 \mathrm{~cm}^{-1}\right)$, carbonyls (1698 and $\left.1630 \mathrm{~cm}^{-1}\right)$, and carbon-carbon double bonds (1490 and $1442 \mathrm{~cm}^{-1}$ ). The ${ }^{1} \mathrm{H}$ NMR (nuclear magnetic resonance) spectrum (Table 1) displayed signals for aldehyde $\delta_{\mathrm{H}} 9.50(\mathrm{~s}, \mathrm{H}-11)$, aromatic $\delta_{\mathrm{H}} 6.41(\mathrm{~s}, \mathrm{H}-3)$, methylidene $\delta_{\mathrm{H}} 6.38(\mathrm{~s}, \mathrm{H}-6 \mathrm{a})$, $6.23(\mathrm{~s}, \mathrm{H}-6 \mathrm{~b})$, and vinyl $\delta_{\mathrm{H}} 4.98(\mathrm{~d}, J 17.2 \mathrm{~Hz})$ and 4.97 $(\mathrm{d}, J 11.0 \mathrm{~Hz})$ to $2 \mathrm{H}-7$ and 5.80 (dd, $J 17.2,11.0 \mathrm{~Hz}, \mathrm{H}-8)$ protons. Additionally, also displayed proton signals for diastereotopic methylene $\delta_{\mathrm{H}} 3.05(\mathrm{~d}, J 17.1 \mathrm{~Hz}, \mathrm{H}-9 \mathrm{a})$ and $2.85(\mathrm{~d}, J 17.1 \mathrm{~Hz}, \mathrm{H}-9 \mathrm{~b})$, a methine proton $\delta_{\mathrm{H}} 3.94(1 \mathrm{H}$, $\mathrm{s}, \mathrm{H}-10 \mathrm{a})$, as well as methoxyl $\delta_{\mathrm{H}} 3.93$ (s, OMe-2) and the methyl groups $\delta_{\mathrm{H}} 1.12(\mathrm{~s}, \mathrm{Me}-12)$. The ${ }^{13} \mathrm{C} \mathrm{NMR}$ spectrum displayed signals for 17 carbon atoms, assigned by heteronuclear single quantum correlation (HSQC) spectra
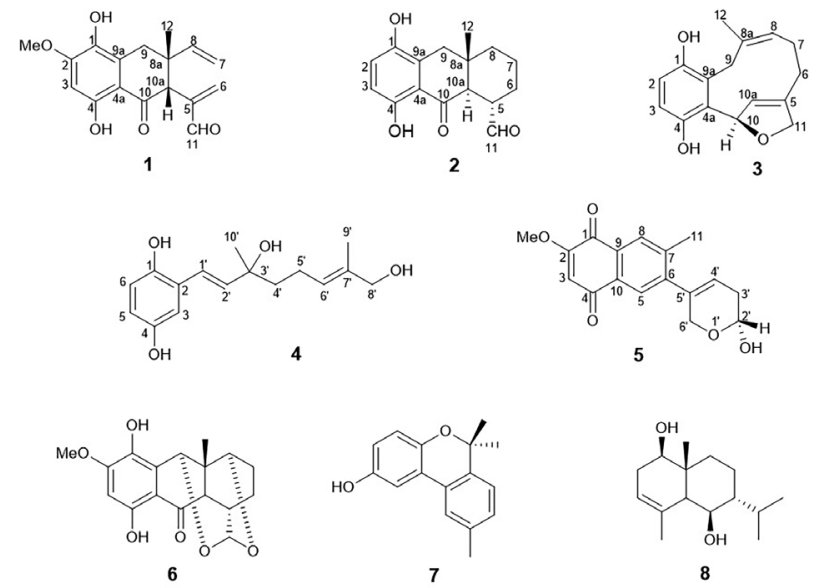

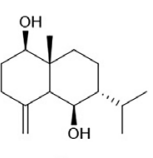

9

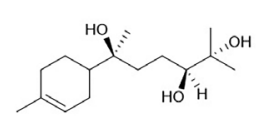

10



11
Figure 1. Structures of compounds 1-11.

into two methyls (including the methoxyl), two carbons $\mathrm{sp}^{3}$ hybridized (methylene and methine), two double bonds (terminal and vinyl), an aldehyde carbonyl at $\delta_{\mathrm{C}} 195.5$ (C-11) and, comparatively, eight non-hydrogenated carbons, including a conjugated ketone carbonyl at $\delta_{\mathrm{C}} 202.7$ (C-10), Table $1 .{ }^{1} \mathrm{H}$ and ${ }^{13} \mathrm{C}$ NMR data analysis were consistent with a 2-methoxy-p-hydroquinone, a vinyl group and an $\alpha, \beta$-conjugated propenal moiety. The heteronuclear multiple bond correlation (HMBC) spectrum showed correlations of the methylidene hydrogens at $\delta_{\mathrm{H}} 6.38 / 6.23$ (2H-6) with the aldehyde carbonyl at $\delta_{\mathrm{C}} 195.5$ (C-11) and $\delta_{\mathrm{C}} 55.4(\mathrm{C}-10 \mathrm{a})$, and the proton at $\delta_{\mathrm{H}} 3.94$ (H-10a) with the carbon at $\delta_{\mathrm{C}} 202.7(\mathrm{C}-10)$ supporting the propenal moiety at the alpha position of the ketone carbonyl. The stereocenter C-8a, bearing a methyl and a vinyl group, was supported by the HMBC correlations of the methylidene vinyl protons at $\delta_{\mathrm{H}} 4.98 / 4.97(2 \mathrm{H}-7)$ with the carbon at $\delta_{\mathrm{C}} 42.8(\mathrm{C}-8 \mathrm{a})$, and the methyl protons at $\delta_{\mathrm{H}} 1.12(\mathrm{Me}-12)$ with the $\mathrm{sp}^{2}$ methine carbon at $\delta_{\mathrm{C}} 143.3(\mathrm{C}-8)$. Additional HMBC correlations, as depicted in Figure 2, supported the suggested planar structure. The relative stereochemistry ascribed to the stereocenters $\mathrm{C}-8 \mathrm{a}\left(R^{*}\right)$ and $\mathrm{C}-10 \mathrm{a}\left(R^{*}\right)$ were determined based on the nuclear Overhauser spectrum (NOESY) correlations between $\mathrm{H}-10 \mathrm{a}$ and the Me-12 (Figure 3) indicating that both vinyl and propenal moieties are cis-vicinally positioned, what is in agreement with previous compounds isolated from other Cordia species. ${ }^{5,6}$ From the above data, the relative configuration of $\mathbf{1}$, named cordiaquinol D, was established as shown in Figure 3.

Compound $\mathbf{2}$ had the molecular formula assigned as $\mathrm{C}_{16} \mathrm{H}_{18} \mathrm{O}_{4}$ based on the deprotonated molecule $[\mathrm{M}-\mathrm{H}]^{-}$at 
Table 1. ${ }^{1} \mathrm{H}(500 \mathrm{MHz}, \mathrm{MeOD})$ and ${ }^{13} \mathrm{C}$ NMR $(125 \mathrm{MHz}, \mathrm{MeO})$ data of compounds 1-3

\begin{tabular}{|c|c|c|c|c|c|c|}
\hline \multirow[b]{2}{*}{ Position } & \multicolumn{2}{|c|}{1} & \multicolumn{2}{|c|}{2} & \multicolumn{2}{|c|}{3} \\
\hline & $\delta_{\mathrm{C}}$ & $\begin{array}{c}\delta_{\mathrm{H}} \text { multiplicity } \\
(\mathrm{J} / \mathrm{Hz})\end{array}$ & $\delta_{\mathrm{C}}$ & $\begin{array}{c}\delta_{\mathrm{H}} \text { multiplicity } \\
(\mathrm{J} / \mathrm{Hz})\end{array}$ & $\delta_{\mathrm{C}}$ & $\begin{array}{c}\delta_{\mathrm{H}} \text { multiplicity } \\
(J / \mathrm{Hz})\end{array}$ \\
\hline 1 & 137.6 & & 148.6 & & 151.2 & \\
\hline 2 & 157.3 & & 125.7 & $7.07 \mathrm{~d}(8.9)$ & 117.2 & $6.62 \mathrm{~d}(8.7)$ \\
\hline 3 & 98.4 & $6.41 \mathrm{~s}$ & 116.0 & $6.69 \mathrm{~d}(8.9)$ & 115.1 & $6.54 \mathrm{~d}(8.7)$ \\
\hline 4 & 160.2 & & 156.6 & & 149.9 & \\
\hline $4 \mathrm{a}$ & 127.0 & & 117.6 & & 127.3 & \\
\hline 5 & 146.8 & & 46.5 & $2.68 \mathrm{~m}$ & 135.4 & \\
\hline 6 & 139.0 & $\begin{array}{l}6.38 \mathrm{~s} \\
6.23 \mathrm{~s}\end{array}$ & 28.0 & $\begin{array}{c}1.97 \mathrm{dd}(13.4,3.5) \\
1.38 \mathrm{~m}\end{array}$ & 28.0 & $\begin{array}{l}2.11 \mathrm{~m} \\
2.06 \mathrm{~m}\end{array}$ \\
\hline 7 & 114.7 & $\begin{array}{l}4.98 \mathrm{~d}(17.2) \\
4.97 \mathrm{~d}(11.0)\end{array}$ & 21.3 & $\begin{array}{l}1.79 \mathrm{~m} \\
1.69 \mathrm{~m}\end{array}$ & 25.1 & $\begin{array}{c}2.30 \mathrm{~d}(12.2) \\
1.90 \mathrm{td}(12.2,2.8)\end{array}$ \\
\hline 8 & 143.3 & $5.80 \mathrm{dd}(17.2,11.0)$ & 41.1 & $\begin{array}{l}1.79 \mathrm{~m} \\
1.69 \mathrm{~m}\end{array}$ & 121.4 & $5.04 \mathrm{t}(8.5)$ \\
\hline $8 \mathrm{a}$ & 42.8 & & 37.2 & & 143.5 & \\
\hline 9 & 34.4 & $\begin{array}{l}3.05 \mathrm{~d}(17.1) \\
2.85 \mathrm{~d}(17.1)\end{array}$ & 41.0 & $\begin{array}{l}3.07 \mathrm{~d}(17.1) \\
2.70 \mathrm{~d}(17.1)\end{array}$ & 28.1 & $\begin{array}{l}3.40 \mathrm{~d}(14.0) \\
2.91 \mathrm{~d}(14.0)\end{array}$ \\
\hline $9 \mathrm{a}$ & 110.7 & & 128.7 & & 128.6 & \\
\hline 10 & 202.7 & & 206.1 & & 83.2 & $6.67 \mathrm{dd}(5.7,3.6)$ \\
\hline $10 \mathrm{a}$ & 55.4 & $3.94 \mathrm{~s}$ & 57.1 & $3.11 \mathrm{~d}(11.0)$ & 126.9 & 5.20 br s \\
\hline 11 & 195.5 & $9.50 \mathrm{~s}$ & 205.7 & $9.81 \mathrm{~d}(3.4)$ & 77.5 & $\begin{array}{c}4.75 \mathrm{dd}(12.0,5,7) \\
4.69 \mathrm{ddd}(12.0,3.6, \\
2.8)\end{array}$ \\
\hline 12 & 26.5 & $1.12 \mathrm{~s}$ & 18.2 & $0.88 \mathrm{~s}$ & 22.4 & $1.59 \mathrm{~s}$ \\
\hline 2-OMe & 56.8 & $3.93 \mathrm{~s}$ & & & & \\
\hline
\end{tabular}

s: singlet; d: doublet; t: triplet; m: multiplet; br s: broad singlet; dd: doublet of doublets; td: triplet of doublets; ddd: doublet of doublet of doublets.

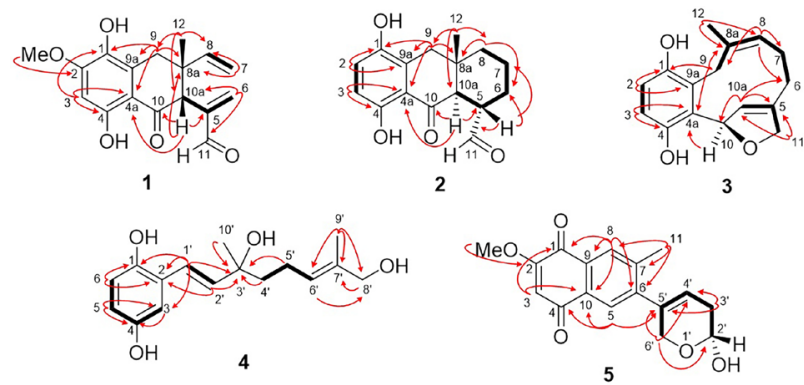

Figure 2. $\mathrm{COSY}(\mathbf{m})$ and $\mathrm{HMBC}(\mathrm{H} \rightarrow \mathrm{C})$ correlations of 1-5.

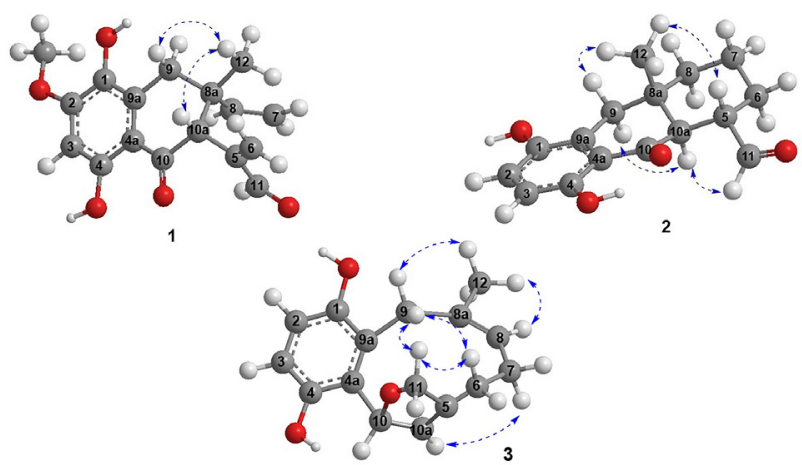

Figure 3. Stick and ball structures of 1-3 depicting the key NOESY correlations of 1-3. $m / z, 273.1129$ (calcd. $m / z, 273.1132$ ) in the HRESIMS spectrum. Its IR spectrum displayed absorption bands for hydroxy $\left(3412 \mathrm{~cm}^{-1}\right)$, carbonyls (1674 and $\left.1631 \mathrm{~cm}^{-1}\right)$, and aromatic ring $\left(1467 \mathrm{~cm}^{-1}\right)$. The ${ }^{1} \mathrm{H}$ NMR spectrum exhibited signals for aldehyde $\delta_{\mathrm{H}} 9.81(\mathrm{~d}, J 3.4 \mathrm{~Hz}, \mathrm{H}-11)$, ortho-positioned protons at $\delta_{\mathrm{H}} 7.07(\mathrm{~d}, J 8.9 \mathrm{~Hz}, \mathrm{H}-2)$ and $6.69(\mathrm{~d}, J 8.9 \mathrm{~Hz}, \mathrm{H}-3)$, two methines $\delta_{\mathrm{H}} 2.68(\mathrm{~m}$, $\mathrm{H}-5)$ and $3.11(\mathrm{~d}, J 11.0 \mathrm{~Hz}, \mathrm{H}-10 \mathrm{a})$, one methyl $\delta_{\mathrm{H}} 0.88$ (s, Me-12), signals for diastereotopic methylene $\delta_{\mathrm{H}} 3.07$ (d, $J 17.1 \mathrm{~Hz}, \mathrm{H}-9 \mathrm{a})$ and $2.70(\mathrm{~d}, J 17.1 \mathrm{~Hz}, \mathrm{H}-9 \mathrm{~b})$, and a series of methylene protons at $\delta_{\mathrm{H}} 1.28-1.97$. The ${ }^{13} \mathrm{C}$ NMR spectrum showed 16 carbon signals assigned by distortionless enhancement by polarization transfer (DEPT $135^{\circ}$ ) and HSQC spectra into one methyl, four methylenes, two methines, two hydrogenated benzene, and seven non-hydrogenated carbon atoms, two of which related to carbonyls at $\delta_{\mathrm{C}} 205.7(\mathrm{C}-11)$ and $206.1(\mathrm{C}-10)$ for an aldehyde and a ketone, respectively. The ${ }^{1} \mathrm{H}$ and ${ }^{13} \mathrm{C}$ NMR data were consistent with a 1,4-hydroquinone similar to 1 , but bearing a third ring which could be formed from 1 by the cyclization at C-6/C-7. Similarly, to $\mathbf{1}$ the aldehyde and the ketone functions, as well as the methyl 
group were positioned at C-5, C-10, and C-8a, respectively, in agreement with the HBMC correlations as summarized in Figure 2. The NOESY spectrum acquired in pyridine $\left(\mathrm{C}_{5} \mathrm{D}_{5} \mathrm{~N}\right)$, Figure S16, Supplementary Information (SI) section showed correlations of the $\beta$-oriented methyl group (Me-12) with the methine proton $\mathrm{H}-5$ and with one proton of the diastereotopic methylene $\mathrm{H}-9 \beta\left(\delta_{\mathrm{H}} 3.07 \mathrm{~d}, J 17.1 \mathrm{~Hz}\right)$, indicated an $\alpha$-orientation for the aldehyde group, while the dipolar interaction of the aldehyde proton $(\mathrm{H}-11)$ with the methine proton $\mathrm{H}-5$ and this with the diastereotopic methylene $\mathrm{H}-9 \alpha\left(\delta_{\mathrm{H}} 2.70 \mathrm{~d}, J 17.1 \mathrm{~Hz}\right)$ confirmed the $\alpha$-orientation for the aldehyde function and transconfiguration of H-10a relatively to the Me-12 (Figure 3). Thus, the structure of compound $\mathbf{2}$ was established and designated of cordiaquinol $\mathrm{E}$.

The molecular formula of $\mathrm{C}_{16} \mathrm{H}_{18} \mathrm{O}_{3}$ of compound 3 was deduced through the protonated molecule $[\mathrm{M}+\mathrm{H}]^{+}$ at $\mathrm{m} / \mathrm{z} 259.1418$ (calcd. $\mathrm{m} / \mathrm{z} 259.1429$ ), as observed by HRESIMS. The ${ }^{1} \mathrm{H}$ and ${ }^{13} \mathrm{C}$ NMR data were similar to those of the globiferin, ${ }^{13}$ but with the quinoid nucleus in the reduced form. This moiety was evidenced by the ortho-positioned hydrogens at $\delta_{\mathrm{H}} 6.62(\mathrm{~d}, J 8.7 \mathrm{~Hz}, \mathrm{H}-2)$ and $6.54(\mathrm{~d}, J 8.7 \mathrm{~Hz}, \mathrm{H}-3)$ and the chemical shifts at $\delta_{\mathrm{C}} 151.2(\mathrm{C}-1), 117.2(\mathrm{C}-2), 115.1$ (C-3), 149.9 (C-4),
$127.3(\mathrm{C}-4 \mathrm{a})$ and $128.6(\mathrm{C}-9 \mathrm{a})$ related to the benzenoid ring. Based on the ${ }^{1} \mathrm{H}$ and ${ }^{13} \mathrm{C}$ NMR data (Table 1) in comparison with those of globiferin, ${ }^{13}$ the structure of 3 was assigned 10,11-dihydrofuran-1,4-dihydroxyglobiferin. Interpretation of the NOESY spectrum, assisted by the three-dimensional molecular structure of $\mathbf{3}$ built by molecular model, showed correlations for the $\delta_{\mathrm{H}} 1.59$ (Me-12) with $\delta_{\mathrm{H}} 3.40(\mathrm{~d}, J 14.0 \mathrm{~Hz}, \mathrm{H}-9)$ and $\delta_{\mathrm{H}} 5.04(\mathrm{t}$, $J 8.5 \mathrm{~Hz}, \mathrm{H}-8)$, between $\delta_{\mathrm{H}} 5.20(\mathrm{br} \mathrm{s}, \mathrm{H}-10 \mathrm{a})$ and $\delta_{\mathrm{H}} 1.90$ (td, $J 12.2,2.8 \mathrm{~Hz}, \mathrm{H}-7$ ), and among the protons $\delta_{\mathrm{H}} 2.11$ $(\mathrm{m}, \mathrm{H}-6), \delta_{\mathrm{H}} 2.91$ (d, J $\left.14.0 \mathrm{~Hz}, \mathrm{H}-9\right)$ and $\delta_{\mathrm{H}} 4.75$ (dd, $J 12.0,5.7 \mathrm{~Hz}, \mathrm{H}-11$ ) suggesting an $R$-configuration for the stereocenter-C10 which was supported by theoretical calculation methods. For the isomers $\mathbf{3 a}(10 S)$ and $\mathbf{3 b}$ $(10 R)$, the calculated ${ }^{13} \mathrm{C}$ chemical shift $\left(\delta_{\text {Ccalc }}\right)$ values were determined using gauge independent atomic orbital $(\mathrm{GIAO})^{14}$ method with mPW1PW91/6-31G(d,p) level of theory whose predicted values are reported in Table 2 in comparison to the experimental ${ }^{13} \mathrm{C}$ chemical shifts $\left(\delta_{\text {Cexp }}\right)$. The results obtained (Figure 4$)$ indicated that the coefficients of determination $\left(\mathrm{R}^{2}\right)$ between the calculated and experimental data from linear regression analysis were 0.9927 (Figure 4a) and 0.9947 (Figure 4b) for 3a and $\mathbf{3 b}$, respectively, suggesting $\mathbf{3 b}(10 R)$ as the presumable

Table 2. Calculated ${ }^{13} \mathrm{C}$ nuclear magnetic shielding $\left(\delta_{\text {ccaldd }}\right)$ using GIAO method with mPW1PW91/6-31G(d,p) level of theory for isomers 3a $(10 S) / \mathbf{3 b}$ $(10 R)$, and $\mathbf{5 a}\left(2^{\prime} S\right) / \mathbf{5 b}\left(2^{\prime} R\right)$ and ${ }^{13} \mathrm{C}$ NMR experimental data $\left(\delta_{\text {cexp }}\right)$

\begin{tabular}{|c|c|c|c|c|c|c|c|c|c|c|c|}
\hline \multirow{2}{*}{$\mathrm{C}$} & \multirow{2}{*}{$\delta_{\text {Cexp }}$} & $\delta_{\text {Ccalcd }}$ & $\delta_{\text {Ccalcd }}$ & $\Delta \delta_{\mathrm{C}}{ }^{\mathrm{a}}$ & $\Delta \delta_{\mathrm{C}}{ }^{\mathrm{a}}$ & \multirow{2}{*}{$\mathrm{C}$} & \multirow{2}{*}{$\delta_{\text {Cexp }}$} & \multirow{2}{*}{$\frac{\delta_{\text {Ccalcd }}}{\mathbf{5 a}(S)}$} & \multirow{2}{*}{$\frac{\delta_{\text {Ccalcd }}}{\mathbf{5 b}(R)}$} & \multirow{2}{*}{$\frac{\Delta \delta_{\mathrm{C}}{ }^{\mathrm{a}}}{\mathbf{5 a}}$} & \multirow{2}{*}{$\frac{\Delta \delta_{\mathrm{C}}^{\mathrm{a}}}{\mathbf{5 b}}$} \\
\hline & & 3a $(S)$ & $\mathbf{3 b}(R)$ & $3 a$ & $3 \mathbf{b}$ & & & & & & \\
\hline 1 & 151.2 & 145.4611 & 144.6314 & 5.7389 & 6.5686 & 1 & 181.3 & 181.7422 & 181.6627 & -0.4422 & -0.3627 \\
\hline 2 & 117.2 & 108.9535 & 110.7789 & 8.2465 & 6.4211 & 2 & 162.3 & 155.7953 & 155.8319 & 6.5047 & 6.4681 \\
\hline 3 & 115.1 & 109.2763 & 109.7169 & 5.8237 & 5.3831 & 3 & 110.8 & 113.4709 & 113.3995 & -2.6709 & -2.5995 \\
\hline 4 & 149.9 & 140.7750 & 144.7028 & 9.1250 & 5.1972 & 4 & 186.5 & 181.9432 & 182.0051 & 4.5568 & 4.4949 \\
\hline $4 a$ & 127.3 & 127.8443 & 125.4793 & -0.5443 & 1.8207 & 5 & 127.5 & 122.6102 & 121.9106 & 4.8898 & 5.5894 \\
\hline 5 & 135.4 & 138.3312 & 141.4512 & -2.9312 & -6.0512 & 6 & 147.1 & 143.5774 & 143.8816 & 3.5226 & 3.2184 \\
\hline 6 & 28.0 & 30.0751 & 26.9964 & -2.0751 & 1.0036 & 7 & 143.9 & 140.2711 & 139.6327 & 3.6289 & 4.2673 \\
\hline 7 & 25.1 & 35.5280 & 30.1266 & -10.428 & -5.0266 & 8 & 129.3 & 128.1594 & 128.2636 & 1.1406 & 1.0364 \\
\hline 8 & 121.4 & 122.2173 & 118.9525 & -0.8173 & 2.4475 & 9 & 131.4 & 126.4381 & 126.0063 & 4.9619 & 5.3937 \\
\hline $8 \mathrm{a}$ & 143.5 & 141.0534 & 138.1829 & 2.4466 & 5.3171 & 10 & 131.4 & 125.7014 & 125.7225 & 5.6986 & 5.6775 \\
\hline 9 & 28.1 & 33.3114 & 31.9102 & -5.2114 & -3.8102 & 11 & 20.4 & 22.8705 & 22.9907 & -2.4705 & -2.5907 \\
\hline $9 a$ & 128.6 & 122.0950 & 124.1246 & 6.5050 & 4.4754 & 2 ' & 92.4 & 88.4461 & 93.0382 & 3.9539 & -0.6382 \\
\hline 10 & 83.2 & 85.6513 & 83.3143 & -2.4513 & -0.1143 & $3^{\prime}$ & 32.6 & 32.3276 & 32.4575 & 0.2724 & 0.1425 \\
\hline $10 \mathrm{a}$ & 126.9 & 127.0580 & 120.2239 & -0.1580 & 6.6761 & $4^{\prime}$ & 123.9 & 123.9666 & 127.899 & -0.0666 & -3.999 \\
\hline 11 & 77.5 & 78.4126 & 78.4776 & -0.9126 & -0.9776 & 5 & 137.8 & 136.0568 & 135.1095 & 1.7432 & 2.6905 \\
\hline \multirow[t]{2}{*}{12} & 22.4 & 31.9853 & 23.5382 & -9.5853 & -1.1382 & 6 ' & 64.9 & 60.6239 & 67.1126 & 4.2761 & -2.2126 \\
\hline & & & & & & 2-OMe & 57.3 & 60.0429 & 60.0452 & -2.7429 & -2.7452 \\
\hline sDP4+ / \% & & 0 & 100 & & & $\mathrm{sDP} 4+/ \%$ & & 58.71 & 41.29 & & \\
\hline uDP4+ / \% & & 4.53 & 95.47 & & & $\mathrm{uDP} 4+/ \%$ & & 0.44 & 99.56 & & \\
\hline $\mathrm{DP} 4+/ \%$ & & 0 & 100 & & & $\mathrm{DP} 4+/ \%$ & & 0.62 & 99.38 & & \\
\hline
\end{tabular}

${ }^{\mathrm{a}} \Delta \delta=\delta_{\text {Cexp }}-\delta_{\text {Ccaldd }}:$ calculated ${ }^{13} \mathrm{C}$ nuclear magnetic shielding deviation. sDP4+: scaled DP4+; uDP4+: unscaled DP4+; DP4+: direct probability 4. 

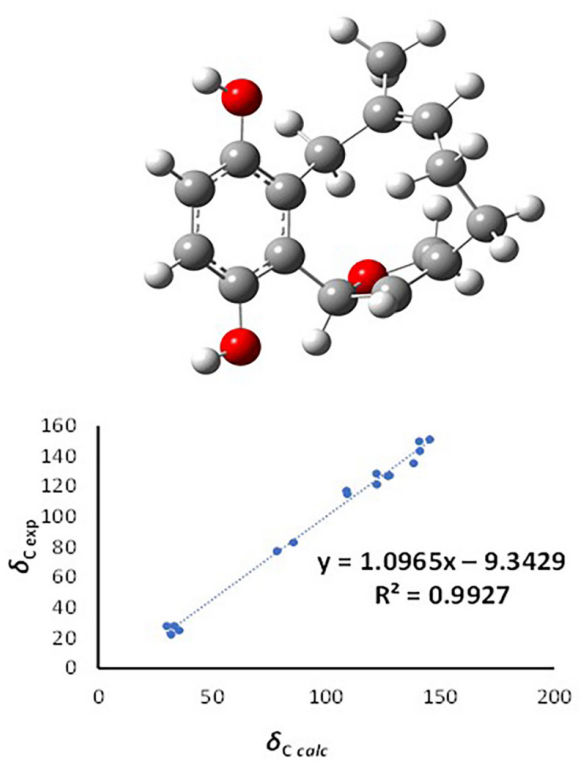

(a)
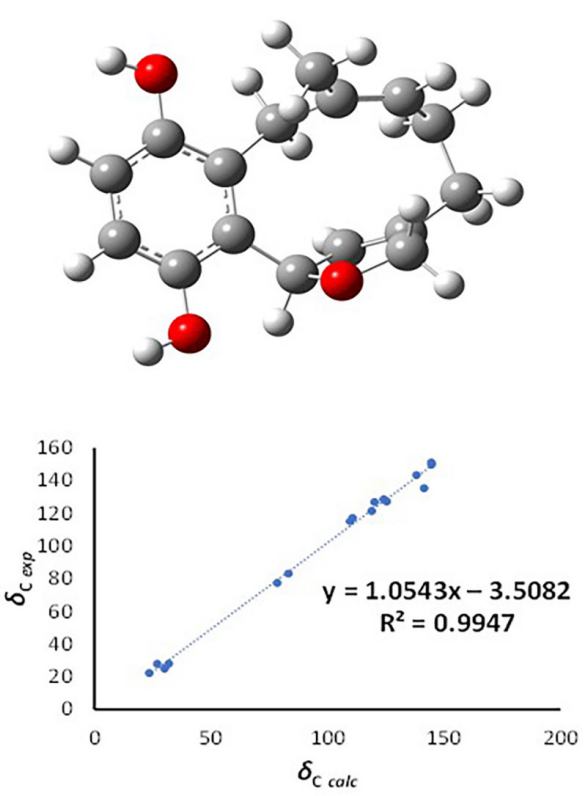

(b)

Figure 4. Optimized geometries and coefficient of determination between the experimental chemical shifts $\left(\delta_{\text {Cexp }}\right)$ versus calculated chemical shifts $\left(\delta_{\text {Caalc }}\right)$ of isomers of compound $\mathbf{3}(10 S(\mathbf{3 a})$ and $10 R(\mathbf{3 b}))$ corresponding to figures (a) and (b), respectively.

compound. To confirm this statement, a complementary analysis using DP4+ modified probability analysis was performed. ${ }^{15}$ Based on the unscaled DP4+ (uDP4+), scaled $\mathrm{DP} 4+(\mathrm{sDP} 4+)$, and DP4+ probabilities, the isomer $\mathbf{3 b}$ (Table 2) was confirmed. Thus, the structure of $\mathbf{3}$ was established as (10R)-10,11-dihydrofuran-1,4-dihydroxyglobiferin.

The molecular formula for compound $4\left(\mathrm{C}_{16} \mathrm{H}_{22} \mathrm{O}_{4}\right)$ was deduced by a combination of the ${ }^{1} \mathrm{H}$ and ${ }^{13} \mathrm{C}$ NMR spectra (Table 3) and the HRESIMS data, which exhibited a protonated ion peak at $\mathrm{m} / \mathrm{z} 243.1381$ (calcd. $\mathrm{m} / \mathrm{z}$ 243.1380) corresponding to the loss of two $\mathrm{H}_{2} \mathrm{O}$ molecules $\left[\mathrm{M}+\mathrm{H}-2 \mathrm{H}_{2} \mathrm{O}\right]^{+}$in comparison with the original molecular formula. The ${ }^{1} \mathrm{H}$ NMR spectrum revealed signals of an $\mathrm{ABC}$ system for a monosubstituted 1,4-hydroquinone moiety at $\delta_{\mathrm{H}} 6.54(\mathrm{~d}, J 8.4 \mathrm{~Hz}, \mathrm{H}-6)$, $6.53(\mathrm{dd}, J$ 8.4, $2.1 \mathrm{~Hz}, \mathrm{H}-5)$ and $6.44(\mathrm{~d}, J 2.1 \mathrm{~Hz}, \mathrm{H}-3)$, a trans-disubstituted double bond $\delta_{\mathrm{H}} 6.29(\mathrm{~d}, J 16.4 \mathrm{~Hz}$, $\left.\mathrm{H}-1^{\prime}\right)$ and 5.60 (d, $\left.J 16.4 \mathrm{~Hz}, \mathrm{H}-2^{\prime}\right)$, an $E$-trisubstituted double bond $\delta_{\mathrm{H}} 5.25\left(\mathrm{t}, J 7.1 \mathrm{~Hz}, \mathrm{H}-6^{\prime}\right)$, as well as signals for methylene protons $\delta_{\mathrm{H}} 4.02\left(\mathrm{~s}, 2 \mathrm{H}-8^{\prime}\right), 2.17$ (m, $2 \mathrm{H}-5$ '), and $1.64\left(\mathrm{~m}, 2 \mathrm{H}-4^{\prime}\right)$ and two methyls at $\delta_{\mathrm{H}} 1.73$ (d, $J 1.2 \mathrm{~Hz}, 3 \mathrm{H}-9$ ') and 1.31 (s, 3H-10'). The ${ }^{13} \mathrm{C}$ NMR displayed 16 carbon atoms, whose hydrogenation patterns were defined, through DEPT $135^{\circ}$ and HSQC spectra, into six monohydrogenated $\mathrm{sp}^{2}$ carbon, three methylenes, two methyls, five non-hydrogenated $\mathrm{sp}^{2}$ carbon atoms, including an oxygenated tertiary carbon (Table 3 ). According to ${ }^{1} \mathrm{H}$ and the ${ }^{13} \mathrm{C}$ NMR data, the difference between $\mathbf{4}$ and its analogous compound 2-(2Z)-(3-hydroxy-3,7-dimethylocta-
Table 3. ${ }^{1} \mathrm{H}(500 \mathrm{MHz}, \mathrm{MeOD})$ and ${ }^{13} \mathrm{C}$ NMR $(125 \mathrm{MHz}, \mathrm{MeOD})$ data of compounds 4 and 5

\begin{tabular}{|c|c|c|c|c|}
\hline \multirow[b]{2}{*}{ Position } & \multicolumn{2}{|r|}{4} & \multicolumn{2}{|r|}{5} \\
\hline & $\delta_{\mathrm{C}}$ & $\begin{array}{c}\delta_{\mathrm{H}} \text { multiplicity } \\
(\mathrm{J} / \mathrm{Hz})\end{array}$ & $\delta_{\mathrm{C}}$ & $\begin{array}{c}\delta_{\mathrm{H}} \text { multiplicity } \\
(J / \mathrm{Hz})\end{array}$ \\
\hline 1 & 147.5 & & 181.3 & \\
\hline 2 & 123.2 & & 162.3 & \\
\hline 3 & 113.9 & $6.44 \mathrm{~d}(2.1)$ & 110.8 & $6.20 \mathrm{~s}$ \\
\hline 4 & 152.2 & & 186.5 & \\
\hline 5 & 117.6 & $6.53 \mathrm{dd}(8.4,2.1)$ & 127.5 & $7.71 \mathrm{~s}$ \\
\hline 6 & 116.5 & $6.54 \mathrm{~d}(8.4)$ & 147.1 & \\
\hline 7 & & & 143.9 & \\
\hline 8 & & & 129.3 & $7.86 \mathrm{~s}$ \\
\hline 9 & & & 131.4 & \\
\hline 10 & & & 131.4 & \\
\hline 11 & & & 20.4 & $2.44 \mathrm{~s}$ \\
\hline 1 ' & 124.1 & $6.29 \mathrm{~d}(16.4)$ & & \\
\hline $2^{\prime}$ & 131.7 & $5.60 \mathrm{~d}(16.4)$ & 92.4 & $5.22 \mathrm{t}(4.3)$ \\
\hline $3^{\prime}$ & 79.1 & & 32.6 & $\begin{array}{l}2.51 \mathrm{~m} \\
2.62 \mathrm{~m}\end{array}$ \\
\hline 4 ' & 42.3 & $1.64 \mathrm{~m}$ & 123.9 & $5.69 \mathrm{~m}$ \\
\hline 5 & 23.5 & $2.17 \mathrm{~m}$ & 137.8 & \\
\hline $6^{\prime}$ & 128.7 & $5.25 \mathrm{t}(7.1)$ & 64.9 & $\begin{array}{l}4.43 \text { ddd }(16.0,4.6,2.1) \\
4.28 \text { ddd }(16.0,4.6,2.4)\end{array}$ \\
\hline $7^{\prime}$ & 135.9 & & & \\
\hline 8 & 61.4 & $4.02 \mathrm{~s}$ & & \\
\hline $9^{\prime}$ & 21.6 & $1.73 \mathrm{~d}(1.2)$ & & \\
\hline $10^{\prime}$ & 26.5 & $1.31 \mathrm{~s}$ & & \\
\hline 2-OMe & & & 57.3 & $3.89 \mathrm{~s}$ \\
\hline
\end{tabular}

s: singlet; d: doublet; t: triplet; m: multiplet; dd: doublet of doublets; ddd: doublet of doublet of doublets. 
1,6-dienyl)-1,4-benzenediol ${ }^{16}$ was the oxymethylene moiety instead of the methyl group at C-7'. Thus, the structure of $\mathbf{4}$ was characterized as the new geranylated hydroquinone designated as 2-[(1'E,6'E)-3', $8^{\prime}$-dihydroxy3',7'-dimethylocta-1',6'-dienyl]-benzene-1,4-diol.

The molecular formula $\mathrm{C}_{17} \mathrm{H}_{15} \mathrm{O}_{5}$ assigned to compound 5 was determined through the deprotonated molecule $[\mathrm{M}-\mathrm{H}]^{-}$ at $m / z 299.0920$ (calcd. 299.0925). The ${ }^{1} \mathrm{H}$ NMR spectrum displayed signals at $\delta_{\mathrm{H}} 7.86$ (s, H-8), 7.71 (s, H-5), 6.20 (s, $\mathrm{H}-3$ ), 3.89 (s, OMe-2) and 2.44 (s, Me-11) of a 2-methoxy1,4-naphthoquinone moiety bearing a methyl group. Additional signals at $\delta_{\mathrm{H}} 5.69(\mathrm{~m}, \mathrm{H}-4$ '), $5.22(\mathrm{t}, J 4.3 \mathrm{~Hz}$, H-2'), 4.43 (ddd, $J$ 16.0, 4.6, $\left.2.1 \mathrm{~Hz}, \mathrm{H}-6^{\prime}\right) / 4.28$ (ddd, $J$ 16.0, 4.6, 2.4 Hz, H-6') and 2.51 (m, H-3')/2.62 (m, H-3') correlating with the carbons at $\delta_{\mathrm{C}} 123.9,92.4,64.9$ and 32.6, respectively, were suggestive of a 3',6'-dihydro- $2 \mathrm{H}$-pyran2 '-ol moiety. The ${ }^{13} \mathrm{C}$ NMR attached proton test (APT) spectrum exhibited 17 carbon signals further classified by HSQC spectra into two methyls, two methylenes, including an oxymethylene, five monohydrogenated carbons (being a hemiketal and four $\mathrm{sp}^{2}$ carbon), and eight non-hydrogenated carbon atoms (Table 3). The 2-methoxy-naphthoquinone framework bearing a 3',6'-dihydro-2 $H$-pyran-2'-ol moiety at $\mathrm{C}-6$ was confirmed by the long-range correlations of $\mathrm{H}-5$ with the non-hydrogenated olefinic carbon at $\delta_{\mathrm{C}} 137.8\left(\mathrm{C}-5^{\prime}\right)$. The relative configuration of the ketal C-2' as $R(\mathbf{5 b})$ was suggested based on theoretically calculated ${ }^{13} \mathrm{C}$ chemical shift $\left(\delta_{\text {Caalc }}\right)$ values in comparison to the experimental ${ }^{13} \mathrm{C}$ chemical shifts $\left(\delta_{\text {Cexp }}\right)$, Table 3 . The coefficients of determination $\left(\mathrm{R}^{2}\right)$ of 0.9962 (Figure 5a) and 0.9967 (Figure 5b) were found for


(a) the stereoisomers $\mathbf{5 a}$ and $\mathbf{5 b}$, respectively, including uDP4+, sDP4+ and DP4+ probabilities values ${ }^{15}$ (Table 2), suggest 5b $\left(2^{\prime} R\right)$ as the most plausible compound. Indeed, the H-2' splitting as a triplet $\delta_{\mathrm{H}} 5.22(\mathrm{~J} 4.3 \mathrm{~Hz})$ due to the similar $J$ values for the axial/equatorial and equatorial/equatorial coupling is in accordance with the suggested stereochemistry through the theoretical calculation. In addition, the ${ }^{13} \mathrm{C}$ NMR chemical shift of C-2' at $\delta_{\mathrm{C}} 92.4$ is in agreement with the axial-position $\left(\delta_{\mathrm{C}} 90.7\right)$ of the hydroxyl versus the equatorialposition $\left(\delta_{\mathrm{C}} 96.0\right)$ as previously observed for compound $\mathbf{1 3}$ (rel-2"'-methoxy-7"'-methyl-1",4"'-naphtalendione$(6$ " $\rightarrow 5$ )-tetrahydropyran-(2eq $\rightarrow O \rightarrow 2 \mathrm{ax})$-tetrahydropyran$\left(5, \rightarrow 6\right.$ "')-2"'-methoxy-7"') in Pessoa et al. ${ }^{17}$ A similar effect of the ${ }^{13} \mathrm{C}$ NMR shielding of axial hydroxy versus equatorial hydroxy is also observe for the anomeric carbons of $\alpha\left(\delta_{\mathrm{C}} 92.9\right)$ and $\beta\left(\delta_{\mathrm{C}} 96.7\right)$ glucopyranose. ${ }^{18}$ Hence, the structure of 5 was stablished as 6-[(2' $R)-2^{\prime}$-hydroxy3',6'-dihydro-2H-pyran-5' -yl]-2-methoxy-7-methylnaphthalene-1,4-dione (5).

Furthermore, the following known compounds were also isolated: rel-1,4-dihydroxy$8 \alpha, 11 \alpha ; 9 \alpha, 11 \alpha$-diepoxy-2-methoxy-8a $\beta$-methyl$5,6,7,8,8 \mathrm{a}, 9,10,10 \mathrm{a}-$ octahydro-10-antracenone $(\mathbf{6}),{ }^{17}$ didehydroconicol (7), ${ }^{19} 1 \beta, 6 \beta$-dihydroxy-7-epi-eudesm3 -ene $(\mathbf{8}),{ }^{20} 1 \beta, 6 \beta$-dihydroxy-7-epi-eudesm-4(15)-ene (9), ${ }^{21}$ 10,11-dihydroxybisabolol (10), ${ }^{22}$ and hamanasal-A (11) ${ }^{23}$ (see Figure 1).

Although there is no experimental support for the biosynthesis of the meroterpenoid 1,4-quinones isolated specifically from Cordia species, a reasonable biosynthetic
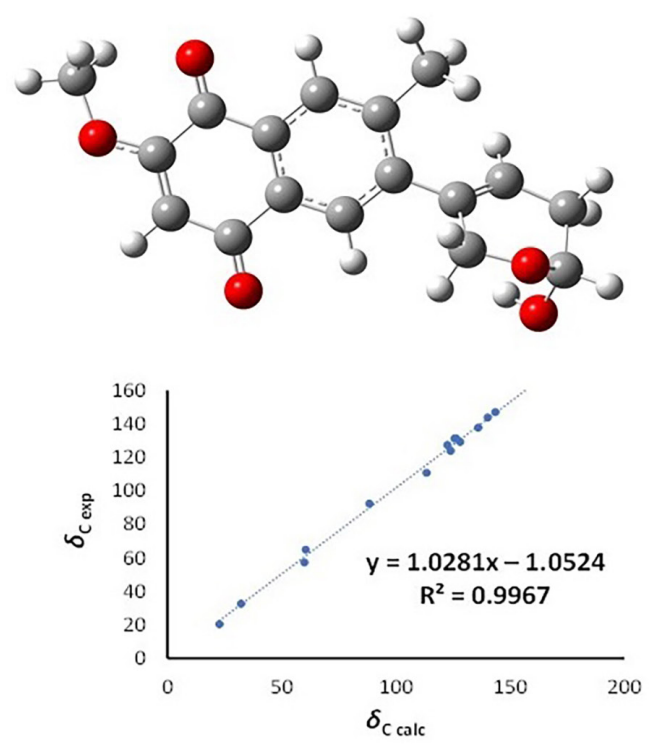

(b)

Figure 5. Optimized geometries and coefficient of determination between the experimental chemical shifts $\left(\delta_{\text {cexp }}\right)$ versus calculated chemical shifts $\left(\delta_{\text {Ccalc }}\right)$ of isomers of compound $\mathbf{5}\left(2^{\prime} S(\mathbf{5 a})\right.$ and $\left.2^{\prime} R(\mathbf{5 b})\right)$ corresponding to figures (a) and (b), respectively. 
pathway for compounds $\mathbf{1}$ to $\mathbf{6}$ was suggested based on previous studies reported to terpenoid quinones. ${ }^{24}$ Thus, it seems reasonable that compounds 1-6 could be produced from a $C$-alkylation of the $p$-hydroxybenzoic acid with two prenyl unities followed by a sequence of typical reactions of the biogenetic process as intramolecular cyclization, oxidation, hydroxylation, and $O$-methylation as depicted in Figure 6.

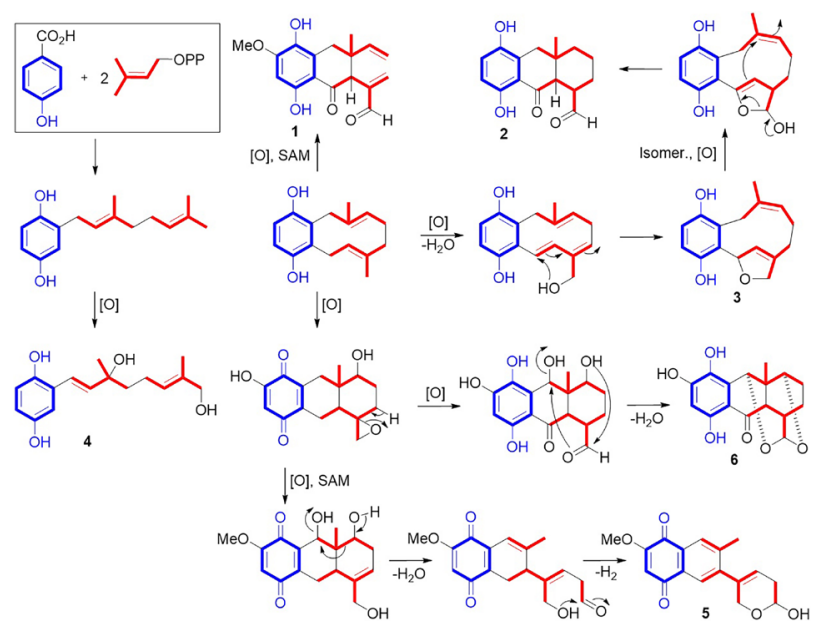

Figure 6. Plausible biogenetic pathways for compounds 1-6.

3-(4,5-Dimethyl-2-thiazolyl)-2,5-diphenyl$2 \mathrm{H}$-tetrazolium bromide (MTT) assay was carried out to evaluate the cytotoxic effects of the compounds on murine macrophages RAW 264.7 cells. ${ }^{25}$ As shown in Table 4, the compounds demonstrated a reduction of the cellular viability with half-maximal inhibitory concentration $\left(\mathrm{IC}_{50}\right)$ values between 71.66-1530.02 $\mu \mathrm{M}$. The concentrations of $6.125,12.5,25$, and $50 \mu \mathrm{M}$ of compounds (no cytotoxicity on RAW264.7 cells) were selected for the subsequent experiments in the present study.

To evaluate the effects of the isolated compounds on the production of sulfated polysaccharides (LPS)-induced oxide nitric (NO) in RAW264.7 cells, the concentrations of $\mathrm{NO}$ in the culture medium were measured by the Griess assay. ${ }^{26} \mathrm{NO}$ levels in the culture supernatants from LPS-stimulated cells were significantly reduced after treatment with the compounds (Table 4). Compounds $\mathbf{3}$, $\mathbf{4}$, and $\mathbf{5}$ were more able to reduce NO production with $\mathrm{IC}_{50}$ values of $50.34 \pm 9.88,105.83 \pm 5.09$, and $66.73 \pm 10.28 \mu \mathrm{M}$, respectively.

\section{Conclusions}

Eleven compounds, including four new terpenoid hydroquinones (1-4) and a naphthoquinone (5), were isolated through the reinvestigation of the $\mathrm{EtOH}$ extract
Table 4. Effects of compounds 2-9 on cell viability and inhibiting nitric oxide production in activated RAW264.7 macrophage cells

\begin{tabular}{lcc}
\hline Compound & Cytotoxicity $\mathrm{IC}_{50}{ }^{\mathrm{a}} / \mu \mathrm{M}$ & $\mathrm{NO}$ inhibition $\mathrm{IC}_{50}{ }^{\mathrm{a}} / \mu \mathrm{M}$ \\
\hline $\mathbf{2}$ & $158.38 \pm 11.05$ & $1420.72 \pm 4.63$ \\
$\mathbf{3}$ & $71.66 \pm 15.44$ & $50.34 \pm 9.88$ \\
$\mathbf{4}$ & $424.82 \pm 6.46$ & $105.83 \pm 5.09$ \\
$\mathbf{5}$ & $166.25 \pm 6.79$ & $66.73 \pm 10.28$ \\
$\mathbf{6}$ & $609.48 \pm 5.05$ & $143.64 \pm 4.67$ \\
$\mathbf{7}$ & $1530.02 \pm 4.54$ & $197.68 \pm 3.84$ \\
$\mathbf{8}$ & $157.20 \pm 6.63$ & $292.04 \pm 3.64$ \\
$\mathbf{9}$ & $355.70 \pm 10.67$ & $235.50 \pm 3.18$ \\
Dexamethasone $^{\mathrm{b}}$ & & $1.79 \pm 0.04$ \\
\hline
\end{tabular}

${ }^{a}$ Half-maximal inhibitory concentration $\left(\mathrm{IC}_{50}\right)$ values are represented as means \pm standard deviation of three independent experiments; ${ }^{b}$ positive control.

from the heartwood of C. glazioviana. It is worth highlighting that similar meroterpenoid compounds have been previously isolated from several Cordia species, and they seem to be restricted to woody plants, in particular, in the roots and trunk heartwood. As a significant number of terpenoid quinones and hydroquinones were previously isolated from Cordia species, it seems reasonable to suggest these compounds as possible chemomarkers for the genus. Eight, out of the eleven isolated compounds (2-9), were tested through cellular viability and lipopolysaccharide (LPS)-induced inflammation assays against RAW 264.7 macrophage-like cells, being compound 3 the one that showed the best reduction of the NO synthesis $\left(\mathrm{IC}_{50} 50.34 \pm 9.88 \mu \mathrm{M}\right)$.

\section{Experimental}

\section{General experimental procedures}

Optical rotations were measured on a Jasco P-2000 polarimeter (Tokyo, Japan), operating with a tungsten lamp at a wavelength of $589 \mathrm{~nm}$ at $20^{\circ} \mathrm{C}$. Melting points were recorded on a digital Marconi MA-381 (Piracicaba, Brazil) apparatus and were uncorrected. Fourier-transform infrared (FTIR) spectra were obtained on a PerkinElmer Spectrum 100 spectrometer (Waltham, USA), using a universal attenuated total reflectance accessory (UATR). The highresolution mass spectra (HRMS) analysis was acquired on a chromatograph coupled to an ion trap mass spectrometer and time-of-flight (LCMS-IT-TOF, Shimadzu, Kyoto, Japan) system as well as on an Acquity UPLC instrument coupled to a Xevo QToF mass analyzer (Waters, Milford, MA, USA). ${ }^{1} \mathrm{H}$ and ${ }^{13} \mathrm{C}$ NMR (1D and 2D) spectra were run on a Bruker Avance DRX-500 spectrometer, using MeOD and $\mathrm{C}_{5} \mathrm{D}_{5} \mathrm{~N}$ 
(Cambridge Isotope Laboratories Inc., Tewksbury, USA) as solvents. The high-performance liquid chromatography (HPLC) separations were achieved on a Shimadzu-UFLC semi-preparative HPLC system, equipped with ternary pumps and diode array SPD-M20A UV/VIS detector using a Phenomenex C18 column (Phenomenex, Torrance, USA) $(250 \times 10 \mathrm{~mm}, 5 \mathrm{~mm})$ and a mobile phase consisting of water was purified in a Milli-Q system (Millipore, St. Louis, USA) with trifluoroacetic acid $\left(\mathrm{CF}_{3} \mathrm{CO}_{2} \mathrm{H}, 0.1 \% \mathrm{v} / \mathrm{v}\right)$ analytical grade was acquired from Vetec (Rio de Janeiro, Brazil) and acetonitrile (MeCN) HPLC grade, were purchased from Tedia (Rio de Janeiro, Brazil), a flow rate of 4.7 or $4.0 \mathrm{~mL} \mathrm{~min}^{-1}$, oven temperature of $40{ }^{\circ} \mathrm{C}$, monitored at $210-400 \mathrm{~nm}$. Chromatography columns (CC) were performed using silica gel 60 (70-230 mesh, Vetec, Rio de Janeiro, Brazil), while the analytical thin-layer chromatography (TLC) was carried out on pre-coated TLC silica gel plates (Merck, Frankfurt, Germany) and the spots visualized by spraying with a vanillin/perchloric acid/EtOH (Vetec, Rio de Janeiro, Brazil and Merck, Frankfurt, Germany) solution followed by heating at $100{ }^{\circ} \mathrm{C}$. All PA solvents were purchased from Labsynth (São Paulo, Brazil).

\section{Plant material}

Cordia glazioviana was collected in April 2012 at Acarape county, Ceará State, Brazil and was authenticated by Dra Maria Iracema Bezerra Loiola, botanist of Departamento de Biologia, Universidade Federal do Ceará (UFC). A voucher specimen (No. 30824) is deposited at the Herbário Prisco Bezerra-UFC. The collection permit was granted by Biodiversity Authorization and Information, SisGen number A86B918.

\section{Extraction and isolation}

The air-dried and milled heartwood $(2.7 \mathrm{~kg})$ of C. glazioviana was macerated with $\mathrm{EtOH}(3 \times 10 \mathrm{~L})$, at room temperature for $24 \mathrm{~h}$ and the resulting solutions were destilled under reduced pressure to yield $91.8 \mathrm{~g}$ of the crude extract. The EtOH extract was solubilized in a mixture of $\mathrm{MeOH}-\mathrm{H}_{2} \mathrm{O} 2: 1$ and partitioned with $n$-hexane, dichloromethane $\left(\mathrm{CH}_{2} \mathrm{Cl}_{2}\right)$ and ethyl acetate (EtOAc) to yield the respective fractions: CGH $(21.8 \mathrm{~g}), \mathrm{CGD}(26.7 \mathrm{~g})$ and CGA (7.5 g). The CGD fraction was fractioned on a silica gel column $(55.1 \mathrm{~g})$ eluting with $n$-hexane-EtOAc $(8: 2,6: 4,4: 6,2: 8, \mathrm{v} / \mathrm{v})$, EtOAc-MeOH (8:2, 6:4, v/v) and $\mathrm{MeOH}$, to yield fractions CGDF1-F7. CGDF1 $(900.0 \mathrm{mg})$ was subjected to a silica gel CC eluted with $n$-hexane, $n$-hexane-EtOAc (9.5:0.5, 9:1, 8:2, 7:3, 6:4, 1:1, v/v) and EtOAc to afford 51 fractions ( $20 \mathrm{~mL}$ each), which were pooled into 5 main subfractions (CGDF1a-CGDF1e) after TLC analysis. CGDF1a (91.2 mg) was subjected to a flash chromatography column eluted with $n$-hexane-EtOAc $1: 1$ $(\mathrm{v} / \mathrm{v})$ to yield compound $\mathbf{1 0}(6.0 \mathrm{mg})$. CGDF1b $(78.0 \mathrm{mg})$ was purified by HPLC using a semi-preparative column and an isocratic solvent system of $\mathrm{H}_{2} \mathrm{O}-\mathrm{MeCN} 1: 1$ at a flow rate of $4.5 \mathrm{~min}^{-1}$ to afford $8(8.0 \mathrm{mg}$, retention time $\left.\left(\mathrm{t}_{\mathrm{R}}\right) 10.2 \mathrm{~min}\right)$ and $9\left(10.1 \mathrm{mg}, \mathrm{t}_{\mathrm{R}} 15.9 \mathrm{~min}\right)$. CGDF1d $(106.1 \mathrm{mg}$ ) was applied to a silica gel column and eluted with $n$-hexane- $\mathrm{CH}_{2} \mathrm{Cl}_{2}(8: 2,6: 4,4: 6,2: 8, \mathrm{v} / \mathrm{v}), \mathrm{CH}_{2} \mathrm{Cl}_{2}$, $\mathrm{CH}_{2} \mathrm{Cl}_{2}$-EtOAc $(9: 1,7: 3,1: 1,3: 7,1: 9, \mathrm{v} / \mathrm{v})$ and EtOAc to give 83 fractions of $8 \mathrm{~mL}$ each, pooled into 6 main fractions after TLC analysis. Fraction $n$-hexane- $\mathrm{CH}_{2} \mathrm{Cl}_{2}$ (4:6, v/v), afforded compound 11 (16.2 mg). CGDF2 $(2.1 \mathrm{~g})$ was subjected to a silica gel column eluted with $n$-hexane, $n$-hexane-EtOAc (9.5:0.5, 9:1, 8:2, 7:3, 6:4, $\mathrm{v} / \mathrm{v}$ ) and EtOAc, to yield fractions CGDF2a-CGDF2f after TLC monitoring. Fraction CGDF2c $(1.0 \mathrm{~g})$ was fractioned over silica gel by elution with $n$-hexane- $\mathrm{CH}_{2} \mathrm{Cl}_{2}(9: 1,8: 2$, 7:3, 6:4, 1:1, 4:6, 3:7, 2:8, v/v) and $\mathrm{CH}_{2} \mathrm{Cl}_{2}$ to yield 70 fractions, which were pooled into 7 subfractions. HPLC analysis of subfraction $n$-hexane- $\mathrm{CH}_{2} \mathrm{Cl}_{2}$ 7:3 $(171.0 \mathrm{mg})$ on a $\mathrm{C}_{18}$ semi-preparative column using a solvent system gradient $\left(\mathrm{H}_{2} \mathrm{O}-\mathrm{MeCN} 1: 1 \rightarrow 3: 7\right.$ in $\left.20 \mathrm{~min}\right)$ at a flow rate of $4.5 \mathrm{~min}^{-1}$, to yield compound $7\left(2.4 \mathrm{mg}, \mathrm{t}_{\mathrm{R}} 13.2 \mathrm{~min}\right)$. CGDF2d (1.1 g) was chromatographed over silica gel and eluted with $n$-hexane- $\mathrm{CH}_{2} \mathrm{Cl}_{2}(8: 2,6: 4,4: 6,2: 8$, v/v), $\mathrm{CH}_{2} \mathrm{Cl}_{2}, \mathrm{CH}_{2} \mathrm{Cl}_{2}$-EtOAc $(8: 2,6: 4, \mathrm{v} / \mathrm{v})$ to give 68 fractions (30 mL each), which were pooled into 5 main fractions (CGDF2d1-CGDF2d5) after TLC analysis. CGDF2d2 was chromatographed over silica gel, eluting with $n$-hexane$\mathrm{CH}_{2} \mathrm{Cl}_{2}\left(8: 2,6: 4,4: 6,2: 8\right.$, v/v), $\mathrm{CH}_{2} \mathrm{Cl}_{2}, \mathrm{CH}_{2} \mathrm{Cl}_{2}$-EtOAc $(8: 2,6: 4,4: 6, \mathrm{v} / \mathrm{v})$ to yield 77 fractions $(5 \mathrm{~mL}$ each), which were combined according to their TLC profile in 4 subfractions. Subfraction $1(150.2 \mathrm{mg})$ was analyzed by HPLC using a $\mathrm{C}_{18}$ semi-preparative column and an aqueous solution of $0.1 \% \mathrm{CF}_{3} \mathrm{CO}_{2} \mathrm{H}$ in $\mathrm{MeCN}(65: 35 \rightarrow 40: 60$ in

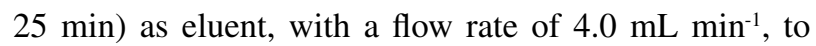
yield $\mathbf{6}\left(5.3 \mathrm{mg}, \mathrm{t}_{\mathrm{R}} 15.9 \mathrm{~min}\right)$ and $\mathbf{2}\left(6.1 \mathrm{mg}, \mathrm{t}_{\mathrm{R}} 17.3 \mathrm{~min}\right)$. The subfraction $4(81.7 \mathrm{mg})$ was fractioned over silica eluted with n-hexane- $\mathrm{CH}_{2} \mathrm{Cl}_{2}(1: 1,4: 6,3: 7,2: 8,1: 9$, $\mathrm{v} / \mathrm{v}), \mathrm{CH}_{2} \mathrm{Cl}_{2}, \mathrm{CH}_{2} \mathrm{Cl}_{2}$-EtOAc (9:1, 8:2, 7:3 v/v) to afford compound $\mathbf{1}(10.0 \mathrm{mg})$ from subfraction $n$-hexane- $\mathrm{CH}_{2} \mathrm{Cl}_{2}$ (2:8). CGDF2e (350.0 mg) was chromatographed on a silica gel column eluting with $n$-hexane- $\mathrm{CH}_{2} \mathrm{Cl}_{2}(7: 3$, 1:1, 3:7, 1:9, v/v) and $\mathrm{CH}_{2} \mathrm{Cl}_{2} / \mathrm{EtOAc}(9: 1,7: 3,1: 1$, v/v) to yield subfractions CGDF2e1-CGDF2e7. Compound $\mathbf{3}$ $(12.0 \mathrm{mg})$ was isolated from CGDF2e7, while $4(6.0 \mathrm{mg}$, $\mathrm{t}_{\mathrm{R}} 11.5 \mathrm{~min}$ ) was obtained from subfraction CGDF2e6 $(176.5 \mathrm{mg})$ after $\mathrm{C}_{18}$ semipreparative $\mathrm{HPLC}\left(\mathrm{H}_{2} \mathrm{O}-\mathrm{MeCN}\right.$ $6: 4)$. The CGA fraction ( $7.5 \mathrm{~g}$ ) was fractionated on a silica 
gel column eluted with $n$-hexane-EtOAc $(8: 2,7: 3,6: 4,1: 1$, 4:6, 3:7 and 2:8, v/v) to yield CGAF1-CGAF7. CGAF2 was subjected to a silica gel CC eluted with $n$-hexane-EtOAc $(9: 1,8.5: 1.5,8: 2,7.5: 2.5,7: 3,6: 4,1: 1,4: 6$ and $3: 7)$ to afford 147 subfractions ( $8 \mathrm{~mL}$ each). Subfractions $125-142$ (114.6 mg) was subjected to a flash chromatography using $n$-hexane-EtOAc 4:6 and further purified by HPLC using a $\mathrm{C}_{18}$ semi-preparative column with the solvent system $\mathrm{H}_{2} \mathrm{O}-\mathrm{MeCN}(75: 25 \rightarrow 55: 45$ in $20 \mathrm{~min})$ and a flow rate of $4.0 \mathrm{~mL} \mathrm{~min}^{-1}$ to afford compound $5\left(9.8 \mathrm{mg}, \mathrm{t}_{\mathrm{R}} 17.2 \mathrm{~min}\right)$.

\section{Computational details}

To establish the relative stereochemistry of compounds $\mathbf{3}$ and 5, two possible isomers of each one of those compounds $(\mathbf{3 a} / \mathbf{3 b}$ and $\mathbf{5 a} / \mathbf{5 b})$ were drawn and their geometrical structures were optimized by using standard techniques. ${ }^{27}$ Optimization calculations were performed by using density functional theory (DFT) ${ }^{28}$ method and a functional version of the PW91 exchange in combination with the original PW91 correlation functional and a mixing ratio of exact and DFT exchange of 0.25:0.75, mPW1PW91 ${ }^{29}$ along with 6-31G(d,p) basis set implemented in Gaussian 16 package. ${ }^{30}$ The frequencies of the optimized geometries were calculated to determine whether the resulting geometries were true minima or transition states on the potential energy surface. All optimization calculations were performed in solution by using the polarizable continuum model (PCM) $)^{31}$ with the integral equation formalism (IEF) ${ }^{32}$ using methanol as solvent. The NMR isotropic shielding constants were determined from the optimized geometries of $\mathbf{3 a} / \mathbf{3 b}$ and 5a/5b with mPW1PW91/6-31G(d,p) level of theory based on the $\mathrm{GIAO}^{14}$ proposal with tetramethylsilane (TMS) as reference implemented in the Gaussian $16 .{ }^{30}$ The integral equation formalism and polarizable continuum model (IEFPCM) solvation method was used with methanol (the solvent used to acquire the ${ }^{1} \mathrm{H}$ and ${ }^{13} \mathrm{C}$ NMR spectra) as an implicit solvent to simulate the medium on the chemical shifts of the stereoisomers. A supplemental analysis that correlates NMR chemical shifts and statistical analysis, named DP4+ allows the use of quantum chemical calculated NMR parameters combined with refined statistical data to elucidate the most likely structure among the stereoisomers. ${ }^{15}$

\section{Assay for cell viability}

Cell viability was assessed using the MTT (SigmaAldrich, St. Louis, USA) assay as described previously. ${ }^{25}$ In brief, RAW 264.7 cells (Merck, Frankfurt, Germany) were seeded into a 96-well plate at a density of $1 \times 10^{4}$ cells per well and incubated at $37{ }^{\circ} \mathrm{C}$ for $24 \mathrm{~h}$. Compounds at different concentrations $(12.5-100 \mu \mathrm{M})$ in dimethyl sulfoxide (DMSO, Romil Chemical Ltd., Cambridge, UK) were added to the cell plate for another $24 \mathrm{~h}$, and then MTT $\left(0.5 \mathrm{mg} \mathrm{mL}^{-1}\right)$ in phosphate-buffered saline (PBS, Merck, Frankfurt, Germany) was added into each well to form the formazan crystals $(3 \mathrm{~h})$. The supernatant was then carefully removed, and $100 \mu \mathrm{L}$ of DMSO was added into each well to dissolve the MTT formazan crystals and measured at $540 \mathrm{~nm}$ using a microplate reader.

\section{Assay for the inhibition of cellular NO production}

The nitrite concentration in the medium was measured by the Griess reagent as an indicator of NO production. ${ }^{26}$ RAW 264.7 cells were seeded into a 96-well plate at a density of $5 \times 10^{5}$ cells per well and incubated at $37^{\circ} \mathrm{C}$ for $24 \mathrm{~h}$. After that, the cells were treated with several sample concentrations $(6.25-50 \mu \mathrm{M})$ or controls $(0.01 \%$ DMSO or $4 \mu \mathrm{M}$ dexamethasone) for $2 \mathrm{~h}$ and then incubated with $1 \mu \mathrm{g} \mathrm{mL}^{-1} \mathrm{LPS}$ for $24 \mathrm{~h}$. To measure the NO in the culture medium, a total of $100 \mu \mathrm{L}$ of culture medium from each sample was mixed with the same volume of Griess reagent and incubated at $37{ }^{\circ} \mathrm{C}$ for $10 \mathrm{~min}$. The absorbance was measured at $540 \mathrm{~nm}$ using a microplate reader.

\section{Cordiaquinol D (1)}

Yellow resin; $[\alpha]_{D}^{20}-22.0$ ( c 0.1, MeOH); IR (ATR) $v_{\max } / \mathrm{cm}^{-1} 3405,1698,1630,1490,1442,1362,1292,1222$, 929, 881; ${ }^{1} \mathrm{H}$ and ${ }^{13} \mathrm{C}$ NMR data, see Table 1; HRESIMS $m / z$, calcd. for $\mathrm{C}_{17} \mathrm{H}_{17} \mathrm{O}_{5}[\mathrm{M}-\mathrm{H}]^{-}:$301.1081, found: 301.1076 .

\section{Cordiaquinol E (2)}

Yellow resin; $[\alpha]_{D}^{20}+16.0$ (c 0.1 , acetone); IR (ATR) $v_{\max } / \mathrm{cm}^{-1} 3412,1674,1631,1467,1257,1214 ;{ }^{1} \mathrm{H}$ and ${ }^{13} \mathrm{C}$ NMR data, see Table 1 ; HRESIMS $\mathrm{m} / \mathrm{z}$, calcd. for $\mathrm{C}_{16} \mathrm{H}_{17} \mathrm{O}_{4}[\mathrm{M}-\mathrm{H}]^{-}: 273.1132$, found: 273.1129 .

(10R)-10,11-Dihydrofuran-1,4-dihydroxy-globiferin (3)

Yellow resin; $[\alpha]_{D}^{20}+2.7$ (c 0.06, acetone); IR (ATR) $v_{\max } / \mathrm{cm}^{-1} 3362,1649,1466,1264,780,703 ;{ }^{1} \mathrm{H}$ and ${ }^{13} \mathrm{C}$ NMR data, see Table 1 ; HRESIMS $\mathrm{m} / \mathrm{z}$, calcd. for $\mathrm{C}_{16} \mathrm{H}_{19} \mathrm{O}_{3}[\mathrm{M}+\mathrm{H}]^{+}:$259.1429, found: 259.1418.

2-[(1'E,6'E)-3',8'-Dihydroxy-3',7'-dimethylocta-1',6'-dienyl]benzene-1,4-diol (4)

Colorless resin; $[\alpha]_{D}^{20}+9.2$ ( 0 0.1, acetone); IR (ATR) $v_{\max } / \mathrm{cm}^{-1} 3307,2967,2918,1484,1456,1203,955,918$, 763, 711; ${ }^{1} \mathrm{H}$ and ${ }^{13} \mathrm{C}$ NMR spectral data, see Table 3; HRESIMS $\mathrm{m} / z$, calcd. for $\mathrm{C}_{16} \mathrm{H}_{19} \mathrm{O}_{2}\left[\mathrm{M}+\mathrm{H}-2 \mathrm{H}_{2} \mathrm{O}\right]^{+}$: 243.1380, found: 243.1381 . 
6-[(2'R)-2'-Hydroxy-3',6'-dihydro-2H-pyran-5'-yl]-2-methoxy-

7-methylnaphthalene-1,4-dione (5)

Yellow resin; $[\alpha]_{D}^{20}-16.0$ (c 0.1, MeOH); IR (ATR) $v_{\max } / \mathrm{cm}^{-1} 3411,2927,1683,1649,1606,1295,1250,906$, 852; ${ }^{1} \mathrm{H}$ and ${ }^{13} \mathrm{C}$ NMR data, see Table 3; HRESIMS $\mathrm{m} / z$, calcd. for $\mathrm{C}_{17} \mathrm{H}_{15} \mathrm{O}_{5}[\mathrm{M}-\mathrm{H}]^{-}: 299.0925$, found: 299.0920 .

\section{Supplementary Information}

Supplementary data are available free of charge at http://jbcs.sbq.org.br as a PDF file.

\section{Acknowledgments}

This study was financed by Coordenação de Aperfeiçoamento de Pessoal de Nível Superior Brasil (CAPES), finance code 001/Fundação Cearense de Apoio ao Desenvolvimento Científico e Tecnológico (FUNCAP, No. 88887.113263/2015-01), Instituto Nacional de Ciência e Tecnologia (INCT BioNat, No. 465637/2014-0), and Conselho Nacional de Desenvolvimento Científico e Tecnológico (CNPq, 309060/2016-8). The authors thank High-Performance Computing Center (NPAD) at Federal University of Rio Grande do Norte (UFRN) and the National High-Performance Processing Center of the Federal University of Ceará (UFC) for providing computational resources and to $\mathrm{CNPq}$ for financial support and the researcher fellowships.

\section{Author Contributions}

AKOS performed the chemical experiments supervised by ODLP; RACS and FAS performed the biological experiments; FCLP, RBF, ERS and KMC performed the NMR and HRMS analyses; NKVM performed the theoretical analysis. ODLP, FAS, KMC, NKVM, and ERS contributed to the writing of the manuscript and its revision.

\section{References}

1. Giles-Rivas, D.; Estrada-Soto, S.; Aguilar-Guadarrama, A. B.; Almanza-Pérez, J.; García-Jiménez, S.; ColínLozano, B.; Navarrete-Vázquez, G.; Villalobos-Molina, R.; J. Ethnopharmacol. 2020, 251, 112543.; Matias, E. F. F.; Alves, E. F.; Silva, M. K. N.; Carvalho, V. R. A.; Coutinho, H. D. M.; Costa, J. G. M.; Braz. J. Pharmacog. 2015, 25, 542.

2. Oza, M. J.; Kulkarni, Y. A.; J. Pharm. Pharmacol. 2017, 69, 755.

3. Dutra, R. C.; Campos, M. M.; Santos, A. R. S.; Calixto, J. B.; Pharmacol. Res. 2016, 112, 4.
4. Basting, R. T.; Spindola, H. M.; Sousa, I. M. O.; Queiroz, N. C. A.; Trigo, J. R.; Carvalho, J. E.; Foglio, M. A.; Biomed. Pharmacother. 2019, 112, 108693; Castro, J.; Rivera, D.; Franco, L. A.; J. Pharm. Invest. 2018, 49, 331; Gupta, R.; Gupta, G.; Pharmacogn. J. 2017, 9, 93.

5. Matos, T. S.; Silva, A. K. O.; Quintela, A. L.; Pinto, F. C. L.; Canuto, K. M.; Filho, R. B.; Fonseca, M. J. S.; Luna-Costa, A. M.; Paz, I. A.; Nascimento, N. R. F.; Silveira, E. R.; Pessoa, O. D. L.; Fitoterapia 2017, 123, 65.

6. Costa, J. G. M.; Pessoa, O. D. L.; Monte, F. J. Q.; Menezes, E. A.; Lemos, T. L. G.; Quim. Nova 2005, 28, 591.

7. Hu, S.; Ma, Y. L.; Guo, J. M.; Wen, Q.; Yan, G.; Yang, S.; Fu, Y. H.; Liu, Y. P.; Nat. Prod. Res. 2020, 34, 3499; Medeiros, R.; Passos, G. F.; Vitor, C. E.; Koepp, J.; Mazzuco, T. L.; Pianowski, L. F.; Campos, M. M.; Calixto, J. B.; Br. J. Pharmacol. 2007, 151, 618; Fernandes, E. S.; Passos, G. F.; Medeiros, R.; Cunha, F. M.; Ferreira, J.; Campos, M. M.; Pianowski, L. F.; Calixto, J. B.; Eur. J. Pharmacol. 2007, 569, 228.

8. Wang, J.; Jin, M.; Jin, C.; Ye, C.; Zhou, Y.; Wang, R.; Cui, H.; Zhou, W.; Li, G.; Nat. Prod. Res. 2020, 34, 3313; Vinh, L. B.; Jang, H. J.; Phong, N. V.; Cho, K.; Park, S. S.; Kang, J. S.; Kim, Y. H.; Yang, S. Y.; Bioorg. Med. Chem. Lett. 2019, 29, 965.

9. Yang, C.; Liu, P.; Wang, S.; Zhao, G.; Zhang, T.; Guo, S.; Jiang, K. F.; Wu, H. C.; Deng, G.; Biochem. Biophys. Res. Commun. 2018, 505, 1; Yi, Y. S.; Kim, M. Y.; Cho, J. Y.; Korean J. Physiol. Pharmacol. 2017, 21, 345.

10. Soares, A. S.; Barbosa, F. L.; Rüdiger, A. L.; Hughes, D. L.; Salvador, M. J.; Zampronio, A. R.; Stefanello, M. E. A.; J. Nat. Prod. 2017, 80, 1837.

11. Gottschling, M.; Miller, J. S.; Syst. Bot. 2006, 31, 361.

12. Costa, J. G. M.; Magalhães, H. I. F.; Lemos, T. L. G.; Pessoa, O. D. L.; Pinheiro, G. M.; Rev. Bras. Farmacogn. 2002, 12, 68.

13. Dettrakul, S.; Surerum, S.; Rajviroongit, S.; Kittakoop, P.; J. Nat. Prod. 2009, 72, 861 .

14. Wolinski, K.; Hinton, J. F.; Pulay, P.; J. Am. Chem. Soc. 1990, 112,8251 .

15. Grimblat, N.; Zanardi, M. M.; Sarotti, A. M.; J. Org. Chem. 2015, 80, 12526; Smith, S. G.; Goodman, J. M.; J. Am. Chem. Soc. 2010, 132, 12946.

16. Ioset, J. R.; Marston, A.; Gupta, M. P.; Hostettmann, K.; J. Nat. Prod. 2000, 63, 424

17. Pessoa, O. D. L.; Lemos, T. L. G.; Carvalho, M. G.; Braz-Filho, R.; Phytochemistry 1995, 40, 1777.

18. Pretsch, E.; Bühlmann, P.; Affolter, C.; Structure Determination of Organic Compounds Tables of Spectra Data, $2^{\text {nd }}$ ed.; Springer: Berlin, 2000.

19. Simon-Levert, A.; Arrault, A.; Bontemps-Subielos, N.; Canal, C.; Banigs, B.; J. Nat. Prod. 2005, 68, 1412.

20. Mahmoud, A. A.; Phytochemistry 1997, 45, 1633.

21. Kamel, A.; J. Nat. Prod. 1995, 58, 428. 
22. Figueroa, M.; Raja, H.; Falkinham, J. O.; Adcock, A. F.; Kroll, D. J.; Wani, M. C.; Pearc, C. J.; Oberlies, N. H.; J. Nat. Prod. 2013, 76, 1007.

23. Hashidoko, Y.; Tahara, S.; Mizutani, J.; Phytochemistry 1992, $31,2148$.

24. Widhalm, J. R.; Rhodes, D.; Hortic. Res. 2016, 3, 16046; Dewick, P. M.; Medicinal Natural Products, A Biosynthetic Approach, $3^{\text {rd }}$ ed.; Wiley: New York, 2009.

25. Mosmann, T.; J. Immunol. Methods 1983, 65, 55.

26. Green, L. C.; Wagner, D. A.; Glogowski, J.; Skipper, P. L.; Wishnok, J. S.; Tannenbaum, S. R.; Anal. Biochem. 1982, 126, 131.

27. Chambers, L. G.; Fletcher, R.; Math. Gaz. 2001, 85, 562.

28. Zinola, C. F.; Electrocatalysis: Computational, Experimental, and Industrial Aspects, $1^{\text {st }}$ ed.; Zinola, C. F., ed.; CRC Press: Boca Raton, 2010.

29. Perdew, J. P.; Burke, K.; Ernzerhof, M.; Phys. Rev. Lett. 1996, 77, 3865.

30. Frisch, M. J.; Trucks, G. W.; Schlegel, H. B.; Scuseria, G. E.; Robb, M. A.; Cheeseman, J. R.; Scalmani, G.; Barone, V.; Petersson, G. A.; Nakatsuji, H.; Li, X.; Caricato, M.; Marenich, A. V.; Bloino, J.; Janesko, B. G.; Gomperts, R.; Mennucci, B.;
Hratchian, H. P.; Ortiz, J. V.; Izmaylov, A. F.; Sonnenberg, J. L.; Williams-Young, D.; Ding, F.; Lipparini, F.; Egidi, F.; Goings, J.; Peng, B.; Petrone, A.; Henderson, T.; Ranasinghe, D.; Zakrzewski, V. G.; Gao, J.; Rega, N.; Zheng, G.; Liang, W.; Hada, M.; Ehara, M.; Toyota, K.; Fukuda, R.; Hasegawa, J.; Ishida, M.; Nakajima, T.; Honda, Y.; Kitao, O.; Nakai, H.; Vreven, T.; Throssell, K.; Montgomery Jr., J. A.; Peralta, J. E.; Ogliaro, F.; Bearpark, M. J.; Heyd, J. J.; Brothers, E. N.; Kudin, K. N.; Staroverov, V. N.; Keith, T. A.; Kobayashi, R.; Normand, J.; Raghavachari, K.; Rendell, A. P.; Burant, J. C.; Iyengar, S. S.; Tomasi, J.; Cossi, M.; Millam, J. M.; Klene, M.; Adamo, C.; Cammi, R.; Ochterski, J. W.; Martin, R. L.; Morokuma, K.; Farkas, O.; Foresman, J. B.; Fox, D. J.; Gaussian 16, Revision C.01, Inc., Wallingford CT, 2016.

31. Mennucci, B.; Wiley Interdiscip. Rev.: Comput. Mol. Sci. 2012, 2, 386 .

32. Mennucci, B.; Cancès, E.; Tomasi, J.; J. Phys. Chem. B 1997, 101, 10506.

Submitted: August 19, 2020

Published online: March 31, 2021 